\title{
Pseudo tumour appearance of vulvar varicose veins
}

\section{Omar Laghzaoui}

Gynécologie Obstetrique, Hôpital Militaire d'Instruction Meknes Maroc, Meknès, Morocco

\section{Correspondence to} Professor Omar Laghzaoui, omar120162@yahoo.fr

Accepted 17 March 2016

\section{DESCRIPTION}

A 26-year-old Moroccan woman consulted the gynaecological emergencies service, for pelvic pain after sex. An interview revealed that the patient had not had a period for 14 weeks; and this was medically supported by her family doctor, who also provided a vulvar biopsy owing to knowledge of a history of cervical cancer in the patient's mother.

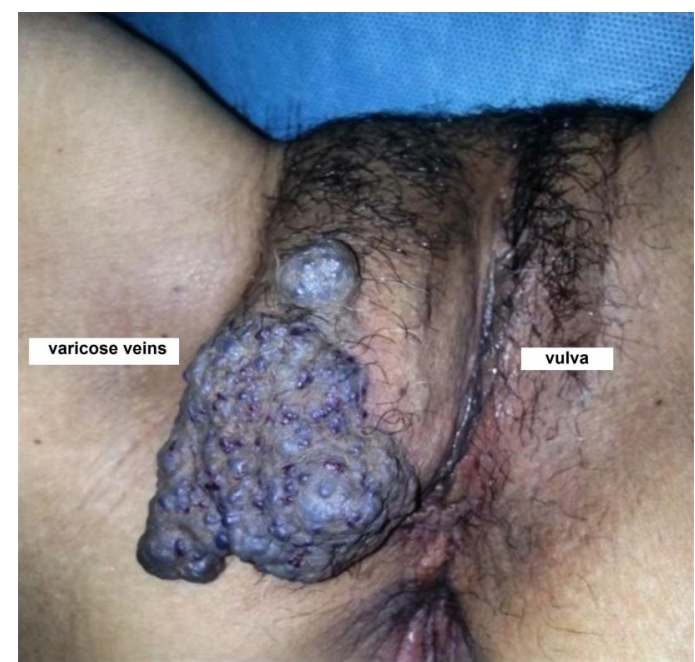

Figure 1 Pseudo tumour appearance of vulvar varicose veins.
Medical examination of the vulva exposed an $8 \times 4 \mathrm{~cm}$ lobe-shaped blackish blue mass, with no pain on palpation (figure 1). Vaginal examination showed a long, closed cervix, with no bleeding. The uterus was enlarged on bimanual examination. No varicose veins were found on inspection of the

\section{Learning points}

- Pregnancy leads to an elevation of pressure in the pelvis, causing difficulty in venous retour, ${ }^{1}$ the slowing down of blood flow and the resultant stagnation in turn increasing the dilation of the vulvar varicose veins.

- Vulvar varicose veins can lead to vulvar tumour requiring a biopsy, which is dangerous because of the possibility of bleeding; exploration of any lesion of the vulva is mandatory before performing invasive action. $^{1} 2$

- Treating varicose veins of the vulva is required because the breakdown of varicose veins during childbirth is likely to cause significant bleeding, compromising the patient's life. ${ }^{2}$ The treatment of vulvar varicose veins using sclerotherapy is not always conclusive, making surgery necessary. ${ }^{3}$
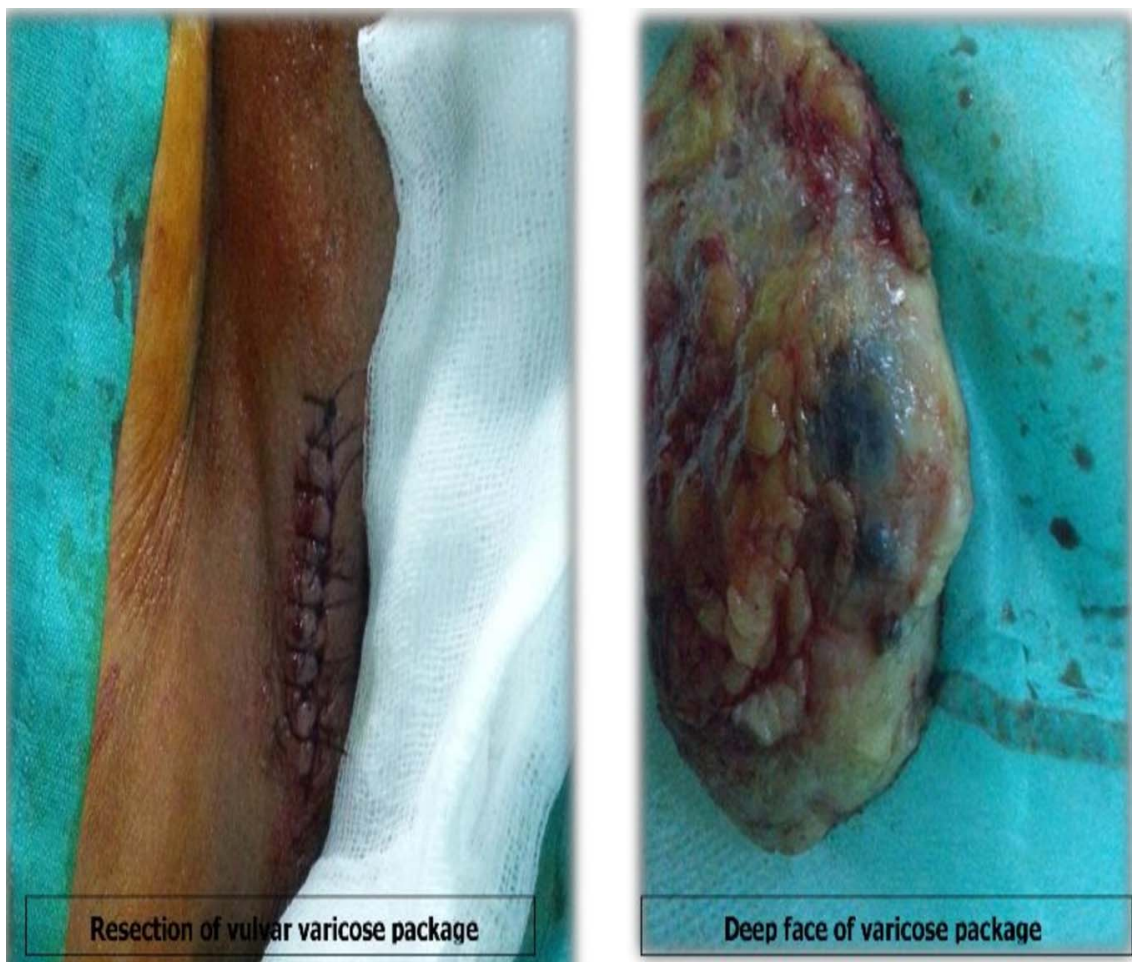

Figure 2 Surgical treatment of vulvar varicose veins. 
thighs and legs. The patient's temperature was normal at $36.9^{\circ} \mathrm{C}$, her weight was $61 \mathrm{~kg}$ and height $1.60 \mathrm{~m}$; blood pressure was 110/70 mm Hg.

Doppler ultrasound made the diagnosis of varicose package vulva and an incontinent great long saphenous vein arch. Transvaginal ultrasound confirmed pregnancy; the biometrics of the fetus corresponded to 14 weeks of amenorrhoea.

Given the large vulvar varicose veins, the discomfort these caused to walking and the risk of injury with bleeding at the time of delivery indicated performing sclerotherapy, to no effect. We opted for surgical ligature of the arch of the long saphenous vein and surgical resection of the varicose package (figure 2). The result was satisfactory, with disappearance of the lesion and the ability for the patient to normally give birth without complications.

Competing interests None declared.

Patient consent Obtained.

Provenance and peer review Not commissioned; externally peer reviewed.

\section{REFERENCES}

1 Cohen-Sacher B, Berger MB, Fenner DE, et al. Vulvar varicosities mimicking a hernia: case report. J Low Genit Tract Dis 2012;16:464-7.

2 Bell D, Kane PB, Liang S, et al. Vulvar varices: an uncommon entity in surgical pathology. Int I Gynecol Pathol 2007;26:99-101.

3 Furuta $\mathrm{N}$, Kondoh E, Yamada S, et al. Vaginal delivery in the presence of huge vulvar varicosities: a case report with MRI evaluation. Eur J Obstet Gynecol Reprod Biol 2013;167:127-31.

Copyright 2016 BMJ Publishing Group. All rights reserved. For permission to reuse any of this content visit http://group.bmj.com/group/rights-licensing/permissions.

BMJ Case Report Fellows may re-use this article for personal use and teaching without any further permission.

Become a Fellow of BMJ Case Reports today and you can:

- Submit as many cases as you like

- Enjoy fast sympathetic peer review and rapid publication of accepted articles

- Access all the published articles

- Re-use any of the published material for personal use and teaching without further permission

For information on Institutional Fellowships contact consortiasales@bmjgroup.com

Visit casereports.bmj.com for more articles like this and to become a Fellow 